\title{
The Concept of Victimology through the Lens of Acid Attack Victims: A Judicial Paradigm
}

\author{
Amlanika Bora ${ }^{1}$, Harshita Priyadarshi ${ }^{2}$ \\ ${ }^{1}$ Assistant Professor, School of Law, Christ University, Bangalore \\ ${ }^{2}$ Student (BALLB), School of Law, Christ University, Bangalore
}

\begin{abstract}
Over the last few years, cases of acid attack have been reported from various parts of India including Rajasthan, Punjab, Madhya Pradesh, Tamil Nadu, Kerala, Bihar, Assam and Delhi. The tragedy and complexity of the problem of acid attack demands a high socio-economic, political and legal concern. Besides other palliative measures, this calls for an attitudinal change as well. The mental agony and societal taboo undergone by the victim of acid attack is unimaginable. It is known that the compensation provided to the acid attack victims is not enough to provide them with sufficient means and various cases have been instituted on the fact that there is a lack of medical care and rehabilitation facilities available to them which have increased the plight of the victims. Thus, the principles have been elucidated on paper but not practically applied in such cases. This paper focuses on the principles of victimology in lieu of its application in cases of acid attacks. It tries to abridge the gap between judicial approach and their stance towards applications of principles of victimology in providing justice and rehabilitation to the victims of acid attack.
\end{abstract}

Keywords: Victim, Victimology, Acid attack victim, Rights of Acid Attack Victim

\section{Introduction}

In today's time, acid attacks have been reported in many parts of the world. Since 1990s, Bangladesh has been reporting the highest number of attacks and highest incidence rates for women with 3,512 Bangladeshi people acid attacked between 1999 and 2013. The position in India, on the other hand, is increasing even after the landmark decision of Laxmi v. Union of India [1], on this regard. In the year 2015, 249 cases were reported in India which was comparatively higher from the previous years. [2]

With the instances of acid attacks on the rise, it is high time to analyze whether adequate machinery has been set up to rehabilitate the acid attack victims or not. It has to be kept in mind that the concept of victimology inherently focuses on the relationship between the victim and the offender and the interactions between the victims and the criminal justice system. The concept of victimology suggests that adequate compensation should be given to the victims of acid attacks for their rehabilitation as well as for their treatment and for the loss of opportunities. However, less heed has been paid by the government to internalize the same. There have been various instances where compensation less than Rs. 2000 have been awarded by the courts and the government has turned a blind eye towards the victims. So in this paper, an attempt has been made to analyze the laws available to tackle the menace of acid attack in India from victim's perspective.

\section{Victimology: A Historical Perspective}

Victimology, in the initial stages, sprouted from criminology, yet has formed into a fully developed discipline in today's time. As of late, there has been a discernible interest and enthusiasm for redressing the plight of victims of crime and thus, a propelling movement towards coordinating or reintegrating them into the criminal justice framework have been seen throughout. However, the identification and considerations of victims in the criminal justice framework can be traced since the Hamurabi Code as well. During the ancient period, victims had many rights and they used to assume a vital part in the criminal justice framework. This was valid amid the rule of Hindu kings and the Muslim period. Despite the fact that their system of criminal trial and punishment was brutal and by and large totally uncouth, the primary aim was to give justice to the victims of crime.

However, with the development of the 'adversarial system of justice', the predicament of the victims turned out to be worse and they got to be distinctly overlooked apart from their minor role in the criminal justice framework as a prosecution witness. It was conjectured that the claim of the victims was adequately fulfilled by the conviction and sentencing of the accused. This assumption is neither reasonable nor just. Justice requires that when society and the State are having recourse to each possible measure of redress and rehabilitation of offenders, equivalent concern must be provided for the victims of crime by providing adequate compensation for their loss and distress including physical and mental torment. This concept of providing justice prompted the advent of a distinct field of criminology which concentrated on the fact whether justice has been served in its actual sense or not. It accordingly became imperative to learn about victims of crimes, the difficulties confronted by such individuals in adapting to the unfavorable impacts of a criminal act, and how could the judicial system compensate and rehabilitate such victims.

Amid primitive times, social control or justice was essentially achieved through individual actions of vengeance, with victims or their families acting as a vigilante by taking the law in their own hands and, basically, assuming the part of judge, jury, and executioner. The view of compensation or rehabilitation was additionally included as a method for expanding punitive sanctions against an offender. The early instances of the same could be found even in the Hamurabi Code. The Code of Hammurabi (1786

\section{Volume 6 Issue 7, July 2017}




\section{International Journal of Science and Research (IJSR) \\ ISSN (Online): 2319-7064 \\ Index Copernicus Value (2015): 78.96 | Impact Factor (2015): 6.391}

B.C.), for instance, spoke of an arrangement of compensation in view of vengeance and savagery and required a victim's family and the society to accept responsibility for helping the victim if the offender was not able to be brought to justice. [3] This Code had extraordinary significance for its concern toward the rights of the victims. It might have been one of the first victims' rights statutes. Be that as it may, it was moderately short lived.

During the Rig Vedic period, the ability to punish the offender vested with the victim. The ancient Hindu law drafters like Manu had entire knowledge of the significance of giving compensation to the victims of crime. It is found that Manu has given reparation to the victims of crime, aside from making the payment of fine to the king. [4] Compensation to the victims of crime for the damage endured was additionally given in the law of Vishnu and Yajnavalakys. According to ancient laws, Yajnavalakys, Narada and Brihaspati describe a method of payment of compensation which would be twice the amount of the purchase money and a fine of an equivalent sum in situations when sale of goods was made falsely or individuals purposefully didn't uncover the defects of the products. These instances, in itself evidences that there was sufficient mechanism in ancient times as well to deal with the rights of the victims and to ascertain that the victims are met with justice.

\section{Victim and Victimology: A Conceptual Analysis}

Victimology may be defined as the scientific study of victimization, including the relationships between victims and offenders, the interactions between the victims and the criminal justice system; that is, the police and courts, and correctional officials. It also includes connections between victims and other social groups and institutions, such as the media, businesses and social movements. [5] In a slender sense, victimology is empirical, factual investigation of victims of crime and in that capacity is firmly identified with criminology and along these lines perhaps viewed as a part of general issue of crime. In a more extensive sense, victimology is the whole body of learning with regards to victims, victimization and the endeavors of society to contradict the rights of the victims. [6] Hence, victimolgy is an entire body of knowledge comprising of various disciplines so as to identify the relationship between victims and offenders with respect to the criminal justice system.

The concept of victim emerges from the concept of justice. Victim belongs to all cultures because it is significantly connected with the idea and practice of sacrifice. The term 'victim' in a general parlance refers to all those who experience injury, loss or hardship due to any cause and one of such causes maybe crime. [7] Therefore, victimology may be defined as a study of people who experience injury or hardship due to any cause. According to Edwin $\mathrm{H}$. Sutherland, criminology is the development of general and verified principles and concerns with the knowledge about the crime, the legal process and treatment of offenders. The criminological study focuses on the etiology of crime and criminal characteristics. On the other hand, victimology is the study of the victim, including the offender and society. Victimology views crime, law, criminal and the victim from a socio structural perspective. [8]

The UN Convention on Justice and Support for Victims of Crime and Abuse of Power defines the victims in Article 1 as:

“(1) 'Victims' means natural persons who, individually or collectively, have suffered harm, including physical or mental injury, emotional suffering or economic loss or violations of fundamental rights in relation to victimizations identified under 'scope'.

(2) A person is a victim regardless of whether the crime is reported to the police, regardless of whether the perpetrator is identified, apprehended, prosecuted or convicted and regardless of the familial relationship between the perpetrator and victim. The term 'victim' also includes, where appropriate, the immediate family or dependents of the direct victims and persons who have suffered in intervening to assist victims in distress or to prevent victimization." [9]

In Section 2 (wa) of the Code of Criminal Procedure, 1973, "Victim means a person who has suffered any loss or injury caused by reason of the act or omission for which the accused person has been charged and the expression victim includes his or her guardian or legal heir." [10] Thus, it can be said that the concept of victim and victimology has been identified in the domestic as well as international plane. Having said this, it is imperative to understand the application of victimology in terms of acid attacks and its victims.

\section{Acid Attack Victims: Position in India}

The modern state is a welfare state in which the welfare of its citizens is of paramount importance. With new developments in the field of victimology, the victims of crime have assumed a significant role. Now, efforts are made for the restitution of the victims. Compensation is awarded with the object of making reparations to the victims or the legal representatives of the deceased. Keeping the welfare of the victims in mind, the author seeks to understand and critically evaluate the shift from an offence centric approach to the victim centric approach when it comes to administering justice to the victims of acid attacks.

Acid attack is, perhaps the most vicious form of crime in the society. It has been steeply rising in past few years and as usual the most of the victim are women and only women. The horrific act of attacking people with acid has been taking place across different parts of country, making the lives of the victims miserable in the aftermath. Although, the offence of acid attack is viewed as not being gender specific, however, in case of India, women, especially young women, have been often subjected to such attacks. Acid attacks have considerably increased in the past few years, and the major reasons accounted are rejecting proposals of marriage, proposals for sex, dowry demands, etc.

\section{Volume 6 Issue 7, July 2017 www.ijsr.net}




\section{International Journal of Science and Research (IJSR) \\ ISSN (Online): 2319-7064}

Index Copernicus Value (2015): 78.96 | Impact Factor (2015): 6.391

Acid attack is a form of violent assault by throwing corrosive substance onto the body of another person with the intention to disfigure the body. Mainly acids are thrown at the face of victim, burning them, and damaging skin tissue, often exposing and sometimes dissolving the bones. The most notable effect of an acid attack is the lifelong bodily disfigurement. The long-term consequence of such type of attack is that it makes the person blind, and very often results in the permanent scarring of the face and body. It makes the life of the person miserable and it also affects their social, economic and psychological life.

Until very recently, there was no specific law in India to deal with the cases of acid attack. Section 326 of the Indian Penal Code which deals with "Voluntarily Causing Grievous Hurt by Dangerous Weapons or Means" [11] was not so effective in dealing with this heinous form of crime because it did not specify acid attack as a separate offence. The $18^{\text {th }}$ Law Commission of India, headed by Justice A.R. Lakshmanan, proposed new sections 326A and 326B in the India Penal Code and section 114B in the Indian Evidence Act.

According to the Section 326A of Indian Penal Code, "acid" includes any substance which has acidic or corrosive character or burning nature that is capable of causing bodily injury leading to scars or disfigurement or temporary or permanent disability. [12] The long term consequences of these attacks may include blindness, as well as permanent scarring of face and body, along with far-reaching social, psychological, and economic difficulties. Section 326A and Section 326B of Indian Penal Code includes punishment which is given to an accused. Section 326A lays down the punishment for "acid throwing". The minimum punishment is 10 years of imprisonment. It can extend up to life imprisonment with fine. Section 326 B lays down the punishment for "attempted acid throwing". The minimum punishment is 5 years imprisonment. It can extend up to 7 years imprisonment with fine.

Furthermore, in cases of acid attack a presumption is incorporated in the Indian Evidence Act as Section 114B. The proposed Section 114B of the Indian Evidence Act provides for presumptions as to acid attacks. [13] It provides that if a person has thrown acid on, or administered acid to, another person, the court shall presume that such an act has been done with the intention of causing, or with the knowledge that such an act is likely to cause such hurt or injury as is mentioned in Section 326 A of the Indian Penal Code. This section was introduced to give wide perspective to acid attack.

The introduction of section 357A in the Criminal Procedure Code by the Amendment Act of 2008 was another welcome move because it gave recognition to the international principle of state obligation to pay compensation to the victims of crime irrespective of identification and prosecution of the accused. Under Section 357A, the State Government in co-ordination with the Central Government is obliged to prepare Victim Compensation Schemes for compensating victims of crimes. Pursuant to the law enacted under section 357A CrPC, various state governments have formulated and notified their respective victim compensation scheme. The Ministry of Home Affairs had issued advisories to the States and Union Territories for framing of the "Victim Compensation Scheme", in the year 2010. The states have enacted their compensation schemes in line with the advisories provided by the Ministry of Home Affairs. In these schemes, compensations have been provided generally for; inter alia, injury caused by acid attack up to Rs.25000300000 .

\section{A Critical Analysis of the Judicial Stance Over Acid Attack Incidents}

Before 2013, India did not have a separate law governing the offence of acid attack and thus, cases have been instituted under different sections of the Indian Penal Code particularly the sections relating to hurt, grievous hurt, grievous hurt by corrosive substances, attempt to murder and murder. In some of the positive cases, the judiciary has held the accused liable for murder, as the intention of the attacker has been construed as an intention to kill the victim. Even in such cases, it has to be stated that the amount of fine which has been levied has often been an insignificant amount. The victim has not been given adequate compensation and has often left on her own to bear the medical expenses.

In the case of Gulab Sahiblal Shaikh v. State of Maharashtra [14], the court sentenced the offender to undergo life imprisonment as per section 302 of Indian Penal Code and a fine of Rs. 1000 was awarded as per the said provision. However, under section 326, he was levied a fine of Rs.2000. It is imperative to note that the learned judge failed to award a suitable compensation in favour of the victim's child who suffered as well during the attack.

In a recent judgment delivered by the Madras High Court in the case of Balu v. State Represented Inspector of Police, [15] the husband who threw acid on his wife causing her death was sentenced to life imprisonment with a meager fine of Rs.2000, which in turn gives us a view that adequate remedy and punitive fines were not imposed on the offender. In Ram Charittar and Anr. v. State of Uttar Pradesh [16], the husband wanted to kill his wife and daughters so as to appropriate the property. He perpetrated an acid attack following which she died. The Supreme Court upheld his conviction but no compensation was awarded to the victims.

One of the earliest cases wherein a suitable amount of compensation was paid in a case of acid attack was in the case of State of Karnataka by Jalahalli Police Station $v$. Joseph Rodrigues. [17] The offender was asked to pay a compensation of Rs. 2lacs to the victim's parents in addition to the Rs.3 lacs fine imposed by the trial court. This was a first case where a large sum was awarded as compensation to meet the medical expenses. However, the compensation did no cover long term consequences such as loss of income, etc.

The Supreme Court of India in yet another decision in Laxmi v. Union of India [18] has equitably strengthened the system to restrain such subsequent instances of acid attacks and bolstered its stand as the guardian of the individual rights and responding to the 'call for justice' prescribed guidelines in order to curb the rampant menace of acid attacks in India. [19] The Supreme Court took a proactive stance and issued

\section{Volume 6 Issue 7, July 2017 www.ijsr.net}




\section{International Journal of Science and Research (IJSR) \\ ISSN (Online): 2319-7064}

Index Copernicus Value (2015): 78.96 | Impact Factor (2015): 6.391

guidelines with a view to curb the menace of acid attacks. These included prohibition of over the counter sale of acid unless a $\log$ /register for the same was maintained; acid could be sold only on the production of a valid government issued photo id; no acid would be sold to any person under the age of 18 years and further, the Court also ordered a complete ban on the sale of acid unless the following requirements are met with.

The Supreme Court has also quantified compensation to be paid to victims of acid attacks under the Victim Compensation Scheme. With regards to the directions given by the Supreme Court, the victims shall be provided with a compensation of Rs. 3 lakhs by the State Government or the Union Territory concerned as the aftercare and rehabilitation cost. A part of the amount i.e. Rs. 1 lakh shall be paid within 15 days of the occurrence of the attack to facilitate immediate medical assistance and the remaining Rs. 2 lakhs shall be paid within a period of 2 months of the attack.

Subsequently, in the case of Parivartan Kendra $v$. Union of India, [20] the Supreme Court ordered that stringent action will be taken against those selling acid without proper authorizations and that the concerned authorities would be also held liable for the inefficiency in keeping a check on the sale and distribution of acid.

As we have seen, in most cases, no compensation has been awarded with the court's simply levying minimal fines without duly considering the victim's plight. Thus, there emerges a great need to set up a criminal injuries compensation board to deal with, in an efficient manner, the victims of acid attack by providing for adequate compensation to meet not just the medical expenses but also for the rehabilitation of the victims and their dependants. The landmark judgment delivered in Laxmi v. Union of India gives us a ray of hope to conclude that the judiciary has not only kept the concept of victimology alive but has also applied them so as to give justice to the victims of acid attacks. However, the paradigm here is that even when the Supreme Court has acted as a guardian of the rights of the citizens, has it achieved what was aimed for? The directions given in the aforementioned case has not been practically applied and still there have been numerous cases which disclose the fact that the directions as well as the punitive approach of the Indian Penal Code is ineffective in dealing with the menace of acid attacks.

\section{Concluding Observation}

Acid attack is possibly one of the worst inflictions on human beings which lead to complete debilitation, loss of opportunity and income and even social sequestration. The mental agony and societal taboo undergone by the victim is unimaginable. The Constitution of India provides ample power to the legislature, executive and judiciary to make, implement and interpret the laws to achieve the preambular goals of liberty, equality, justice and fraternity; to protect the rights of citizen of India. Then why is that nothing has been done to rehabilitate and help the victims to overcome the trauma suffered by them? The answer lies in the application and internalization of the concept of victimology. Even though the concepts are applied and sought to on paper, the application of the same is missing. The lens through which the acid attack victims see the concept of victim rehabilitation has been blurred due to the fact that the government and the judiciary has not taken adequate steps to stop this menace. The bridge between the victims and the authorities seems to be widening day by day. The judiciary has, at times, dealt with the incident of acid attack in a proactive way and has went a step ahead by granting compensation for medical needs as well. However, what is much needed in today's time is that the faith in the system should be maintained and the age old concept of victimology to be brought to life by its application so that the victims could be rehabilitated and do not suffer hard times because of their loss.

\section{References}

[1] (2014) 4 SCC 427

[2] Acid Survivors Foundation India, http://www.asfi.in (Accessed on 13.03.2017).

[3] Harvey Wallace and Cliff Roberson, Victimology Legal, Psychological and Social Perspectives 05, Prentice Hall, New Jersey, 2011.

[4] Manusmriti: A Critique of the Criminal Justice Tenets in the Ancient Indian Hindu Code, available at http://www.erces.com/journal/articles/archives/v03/v03 _05.htm, (Accessed on 12.03.2017).

[5] Paranjape, Dr. N.V., Criminology and Penology with Victimology, $15^{\text {th }}$ Ed., Central Law Publications Ltd., Allahabad, 2011, p. 663.

[6] Randhawa, Gurpreet Singh, Victimology and Compensatory Jurisprudence, $1^{\text {st }}$ Ed., Central Law Publications, Allahabad, 2011, p. 123.

[7] Paranjape, supra note 3, p. 663.

[8] Ann Wolbert Burgess, Cheryl Regehr, et.all., Victimology Theories and Applications, Jones and Bartlett Publishers, Sudbury, Massachusetts, 2010.

[9] United Nations, General Assembly, Declaration of Basic Principles of Justice for Victims of Crime and Abuse of Power, 29 ${ }^{\text {th }}$ November 1985, http://www.un.org/documents/ga/res/40/a40r034.htm, Last Accessed on 13.03.2017

[10] Section 2(wa) of the Code of Criminal Procedure, 1973 [Inserted by Amendment Act of 2009 Act 5 of 2009)]

[11] Section 326, Indian Penal Code, 1860.

[12] Section 326A, Indian Penal Cose, 1860.

[13] Section 114B, Indian Evidence Act, 1872.

[14] 1998 BomCR (Cri).

[15] Balu v. State Represented Inspector of Police, Decided on 26.10.2006

[16] Appeal (crl.) 329 of 2006

[17] State of Karnataka by Jalahalli Police Station vs. Joseph Rodrigues, Decided in the Hon'ble High Court of Kerala on 22/8/2006.

[18] (2014) 4 SCC 427

[19] NALSA (LEGAL SERVICES TO THE VICTIMS OF ACID ATTACKS) SCHEME, 2016, National Legal Services Authority, Pg. 6.

[20](2015) 43 SCD 158 